\title{
Autosomal dominant brachyolmia
}

INSERM

\section{Source}

INSERM. (1999). Orphanet: an online rare disease and orphan drug data base. Autosomal dominant brachyolmia. ORPHA:93304

Autosomal dominant brachyolmia is a relatively severe form of brachyolmia (see this term), a group of rare genetic skeletal disorders, characterized by short-trunked short stature, platyspondyly and kyphoscoliosis. Degenerative joint disease (osteoarthropathy) in the spine, large joints and interphalangeal joints becomes manifest in adulthood. 